\title{
Differences in Proteinase $K$ Resistance and Neuronal Deposition of Abnormal Prion Proteins Characterize Bovine Spongiform Encephalopathy (BSE) and Scrapie Strains
}

\author{
Thorsten Kuczius and Martin $\mathbf{H}$. Groschup \\ Federal Research Centre for Virus Diseases of Animals, Tübingen, \\ Germany \\ Communicated by C. Weissmann. Accepted May 3, 1999.
}

\begin{abstract}
Prion diseases are associated with the accumulation of an abnormal isoform of host-encoded prion protein $\left(\operatorname{PrP}^{\mathrm{Sc}}\right)$. A number of prion strains can be distinguished by "glycotyping" analysis of the respective deposited $\mathrm{PrP}^{\mathrm{Sc}}$ compound. In this study, the long-term proteinase $\mathrm{K}$ resistance, the molecular mass, and the localization of $\operatorname{Pr} \mathrm{P}^{\mathrm{Sc}}$ deposits derived from conventional and transgenic mice inoculated with 11 different BSE and scrapie strains or isolates were examined. Differences were found in the long-term proteinase $\mathrm{K}$ resistance $\left(50 \mu \mathrm{g} / \mathrm{ml}\right.$ at $\left.37^{\circ} \mathrm{C}\right)$ of $\operatorname{PrP}^{\mathrm{Sc}}$. For example, scrapie strain Chandler or PrP ${ }^{\mathrm{Sc}} \mathrm{de}-$ rived from field BSE isolates were destroyed after $6 \mathrm{hr}$ of exposure, whereas $\operatorname{PrP}^{\mathrm{Sc}}$ of strains $87 \mathrm{~V}$ and ME7 and of
\end{abstract}

the Hessenl isolate were extremely resistant to proteolytic cleavage. Nonglycosylated, proteinase $\mathrm{K}$-treated $\mathrm{PrP}^{\mathrm{Sc}}$ of BSE isolates and of scrapie strain $87 \mathrm{~V}$ exhibited a 1-2 kD lower molecular mass than $\operatorname{PrP}^{\mathrm{Sc}}$ derived from all other scrapie strains and isolates. With the exception of strain $87 \mathrm{~V}, \mathrm{PrP}^{\mathrm{Sc}}$ was generally deposited in the cerebrum, cerebellum, and brain stem of different mouse lines at comparable levels. Long-term proteinase resistance, molecular mass, and the analysis of $\mathrm{PrP}^{\mathrm{Sc}}$ deposition therefore provide useful criteria in discriminating prion strains and isolates (e.g., BSE and 87V) that are otherwise indistinguishable by the PrP ${ }^{S c}$ "glycotyping" technique.

\section{Introduction}

Transmissible spongiform encephalopathies (TSEs), also known as prion diseases, are fatal infectious diseases affecting humans [Creutzfeldt-Jakob disease (CJD), Gerstmann-Sträussler-Scheincker syndrome (GSS), fatal familial insomnia (FFI), and kuru], sheep, goats and mouflon (scrapie), cattle [bovine spongiform encephalopathy (BSE)], mink [transmissible mink encephalopathy], and deer [chronic wasting disease]. In the course of these diseases an isoform of cellular prion protein $\left(\mathrm{PrP}^{\mathrm{C}}\right)$ accumulates as a pathological prion protein $\left(\mathrm{PrP}^{\mathrm{Sc}}\right)$

Address correspondence and reprint requests to: Dr. Martin H. Groschup, Federal Research Centre for Virus Diseases of Animals, P.O. Box 1149, 72001 Tübingen, Germany. Phone: 49-7071-967-0; Fax: 49-7071-967-303; E-mail martin.groschup@tue.bfav.de in the nervous and lymphatic systems (1-3). According to the prion theory, $\operatorname{PrP}^{\mathrm{Sc}}$ itself constitutes the infectious agent (4). Host-encoded $\operatorname{PrP}^{C}$ is widely expressed in neuronal cells as a cell-membrane protein with a molecular mass of $33-36 \mathrm{kD}$ in a fully matured and diglycosylated form. Its physiological function is as yet unknown. In pulsechase experiments on neuroblastoma cells (N2a cells) infected by the scrapie strain Chandler, $\operatorname{PrP}^{\mathrm{C}}$ had a half-life of less than $4 \mathrm{hr}$, whereas $\operatorname{PrP}^{\mathrm{Sc}}$ was metabolically stable for $48 \mathrm{hr}$ and longer (5). In contrast, $\mathrm{PrP}^{\mathrm{Sc}}$ is distinguished from $\operatorname{PrP}^{\mathrm{C}}$ by physicochemical features: it forms insoluble aggregates, the scrapie-associated fibrils (SAFs), also termed prion rods $(6-11)$. Furthermore, it is partially resistant to proteinase $\mathrm{K}$ digestion $(4,12,13)$; for instance, proteinase $\mathrm{K}$ only cleaves off $60-70$ resi- 
Table 1. Incubation times of BSE and scrapie strains and isolates in rodent TSE models

\begin{tabular}{|c|c|c|c|}
\hline $\begin{array}{l}\text { Strain/ } \\
\text { isolate }\end{array}$ & Source/host species & $\begin{array}{l}\text { Rodent species or } \\
\text { breed used for prion } \\
\text { propagation }\end{array}$ & $\begin{array}{c}\text { Incubation time } \\
\text { (days } \pm \text { SEM) }\end{array}$ \\
\hline \multirow[t]{3}{*}{ Chandler } & Mouse scrapie strain & C57BL/6 mice & $164 \pm 4.7$ \\
\hline & & CD-1 mice & $147 \pm 5.1$ \\
\hline & & $\operatorname{Tg} 20$ mice & $65 \pm 0.7$ \\
\hline \multirow[t]{2}{*}{$22 \mathrm{~A}$} & Mouse scrapie strain & C57BL/6 mice & $481 \pm 3.4$ \\
\hline & & VM95 mice & $195 \pm 1.2$ \\
\hline ME7 & Mouse scrapie strain & C57BL/6 mice & $179 \pm 7.9$ \\
\hline $79 \mathrm{~A}$ & Mouse scrapie strain & C57BL/6 mice & $169 \pm 10.9$ \\
\hline $87 \mathrm{~V}$ & Mouse scrapie strain & VM95 mice & $370 \pm 11.3$ \\
\hline $263 \mathrm{~K}$ & Hamster scrapie strain & Syrian hamster & $83 \pm 1.8$ \\
\hline Hessen 1 & Sheep scrapie isolate & C57BL/6 mice & $296 \pm 7.3$ \\
\hline S833 & Sheep scrapie isolate & C57BL/6 mice & $142 \pm 12.3$ \\
\hline S540 & Sheep scrapie isolate & C57BL/6 mice & $442 \pm 3.2$ \\
\hline \multirow[t]{2}{*}{ BSE-UK } & Cattle BSE isolate & C57BL/6 mice ${ }^{a}$ & $202 \pm 6.2$ \\
\hline & & VM95 mice ${ }^{b}$ & $339 \pm 3.6$ \\
\hline \multirow[t]{2}{*}{ BSE-G } & Cattle BSE isolate & C57BL/6 mice ${ }^{a}$ & $197 \pm 7.0$ \\
\hline & & VM95 mice ${ }^{b}$ & $353 \pm 12.1$ \\
\hline
\end{tabular}

${ }^{a}$ Isolated in a C57BL/6 mouse and subpassaged there.

${ }^{b}$ Isolated in a C57BL/6 mouse and subpassaged in VM95 mice.

dues (the exact number depends on the species and strain of agent) of the 211-221 residues encompassing the amino acid backbone of post-translationally processed $\mathrm{PrP}^{\mathrm{Sc}}$, leaving behind a resistant core fragment with a molecular mass of 27-30 $\mathrm{kD}$, if in diglycosylated form. In contrast to $\operatorname{PrP}^{\mathrm{C}}$, $\operatorname{PrP}^{\mathrm{Sc}}$ contains a high $\beta$-sheet content (14-16).

A variety of different prion strains have been discovered that can be distinguished according to differences in their transmissibility, incubation time, induced clinical symptoms, brain lesions, and resistance to inactivation (17-24). Western blot analysis has revealed that nonglycosylated, proteinase $\mathrm{K}$-treated $\mathrm{PrP}^{\mathrm{Sc}}$ of the scrapie strain $87 \mathrm{~V}$ and of the transmissible mink encephalopathy (TME) strain "Hyper" exhibit a 1-2 kD lower molecular mass than $\operatorname{PrP}^{\mathrm{Sc}}$ accumulated during the infection of mice or hamsters with other scrapie or TME strains (25-26). Three different molecular masses of nonglycosylated CJDderived $\mathrm{PrP}^{\mathrm{Sc}}$ have been reported (27), whereby $\mathrm{PrP}^{\mathrm{Sc}}$ derived from the new variant CJD (nvCJD) clusters into the category of low molecular mass (27). A low molecular mass was also reported for BSE-derived $\operatorname{PrP}^{\mathrm{Sc}}$. However, no data are as yet available on the molecular masses of mousepassaged scrapie-derived $\mathrm{PrP}^{\mathrm{Sc}}$ prions obtained from diseased individuals of the same host species.

Comparative analysis of glycoform ratios (nonglycosylated, monoglycosylated, and diglycosylated fraction of $\mathrm{PrP}^{\mathrm{Sc}}$ ) is another useful means for discriminating TSE strains (so-called glycotyping). In conventional cases of CJD, GSS, and kuru (27), as well as in mice infected with the scrapie strains Chandler and 79A, the monoglycosylated fraction is the major compound of $\operatorname{PrP}^{\mathrm{Sc}}(28,29)$. In contrast, infections with the nvCJD, BSE, and scrapie strains 87V and 263K lead to the aberrant deposition of diglycosylated $\operatorname{PrP}^{\text {Sc }}$ (27-29).

Molecular analysis of the deposited $\operatorname{PrP}^{\mathrm{Sc}}$ has thus provided important criteria for the discrimination of prion strains. It must be noted, however, that $\mathrm{PrP}^{\mathrm{Sc}}$ produced in the course of infection by certain strains or isolates (e.g., BSE and $87 \mathrm{~V}$ ) are hardly distinguishable at all by the glycotyping technique. In the current study, we introduce further criteria for the characterization of strains or isolates. We were able to demon- 
A

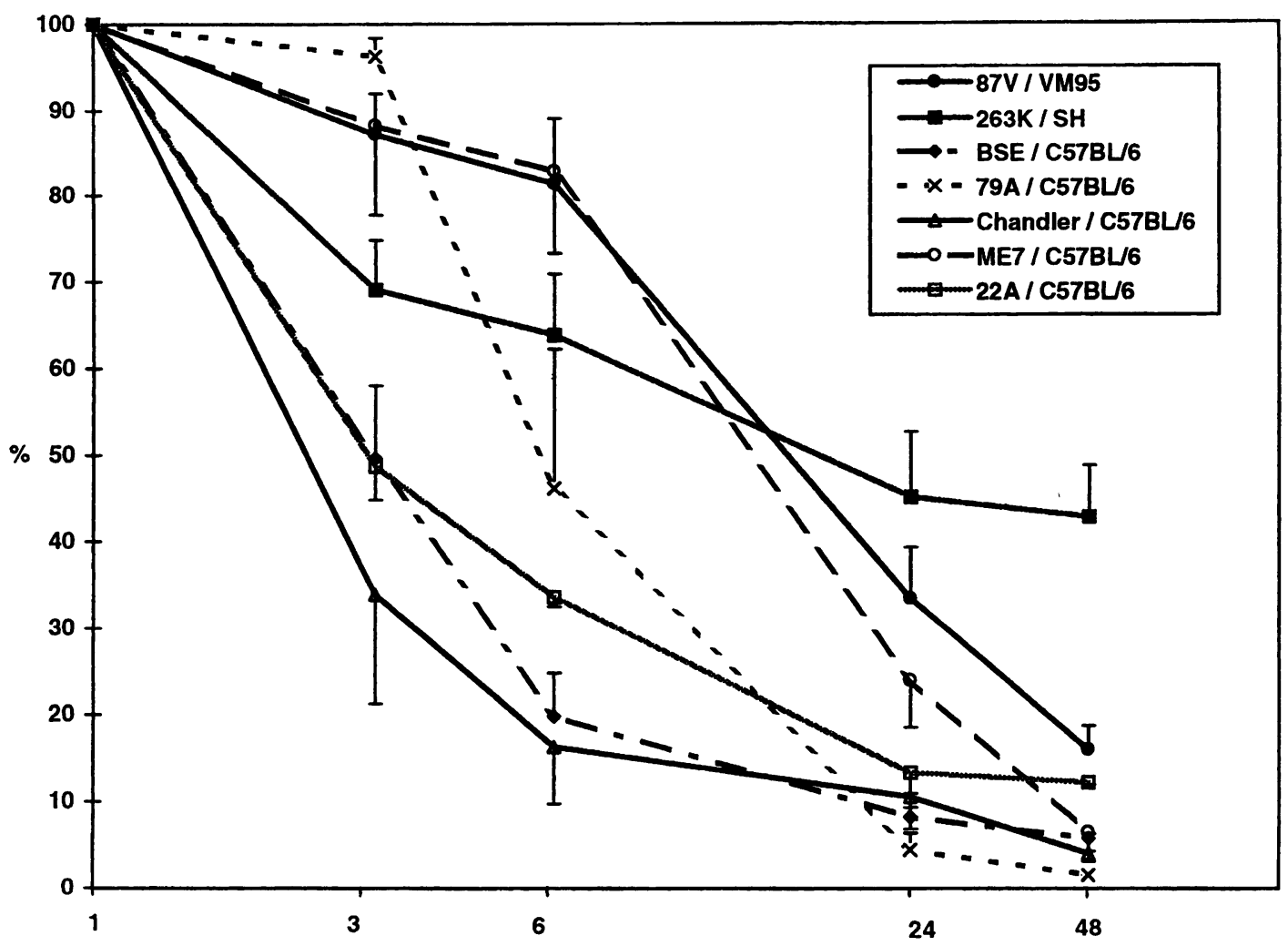

Proteinase K-digestion ( $h$ )

B

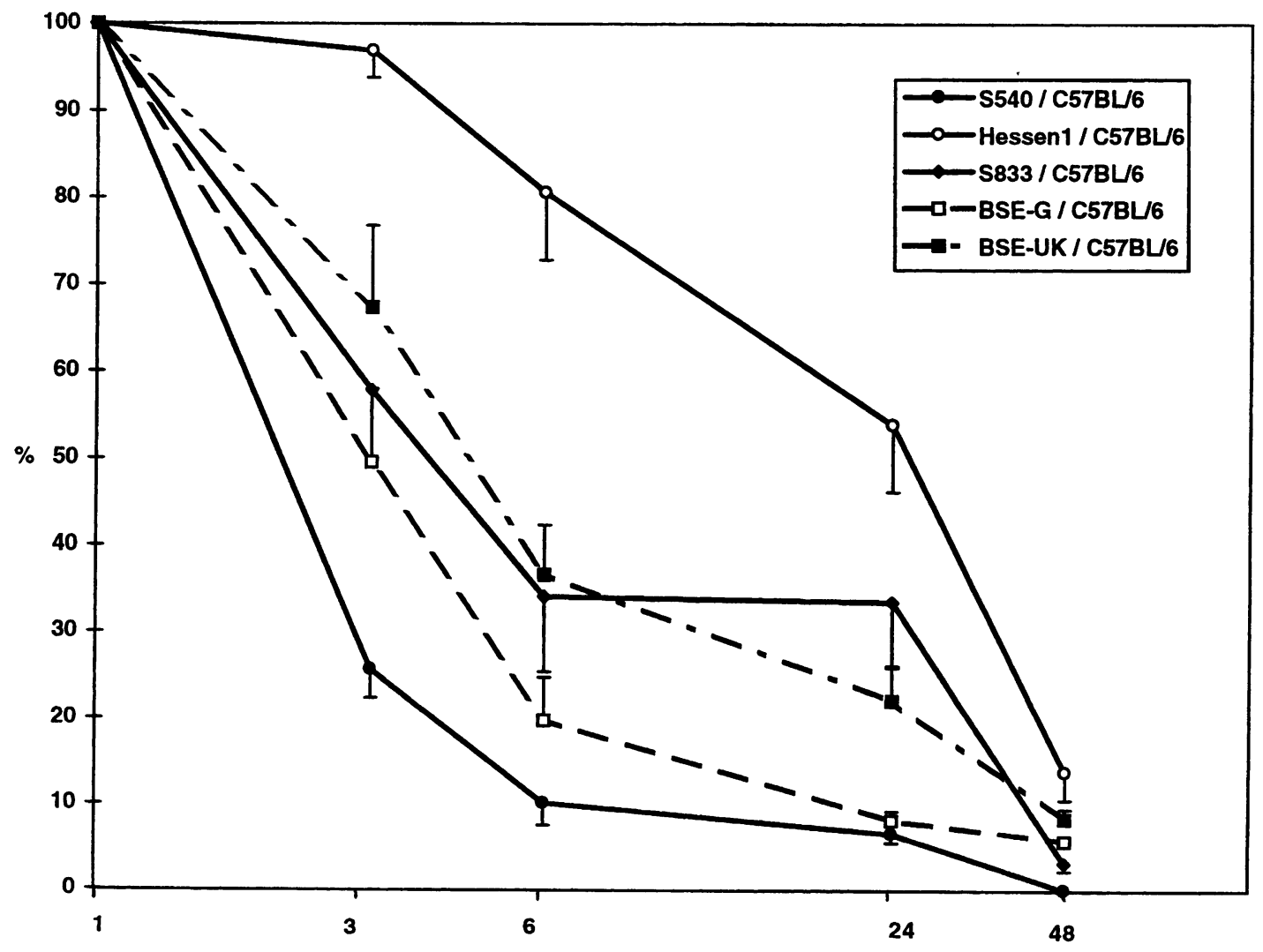

Proteinase K-digestion (h) 
strate that $\mathrm{PrP}^{\mathrm{Sc}}$ resists the long-term exposure to proteinase $\mathrm{K}$ and followed this up by comparing the molecular mass of proteinase $\mathrm{K}$-treated $\mathrm{PrP}^{\mathrm{Sc}}$ of mouse-passaged BSE and scrapie strains, as well as by quantitatively analyzing the distribution of PrP ${ }^{\mathrm{Sc}}$ deposits in different sites in the brain. The data presented here confirm the existence and distinctiveness of prion strains and underline the fact that BSE isolates can be distinguished from experimental and field scrapie strains or isolates by physicochemical analysis.

\section{Materials and Methods}

\section{Propagation of BSE and Scrapie Strains}

C57BL/6 mice were intracerebrally inoculated (20 $\mu \mathrm{l}$ of $1 \%$ mouse brain homogenate) with cloned mouse scrapie strains ME7, 22A, 79A, and $87 \mathrm{~V}$ (kindly provided by $\mathrm{M}$. Bruce, BBSRC 8 MRC Neuropathogenesis Unit, Edinburgh) and with the Chandler strain (kindly provided by C. Weissmann, University of Zürich). Similarly, VM95 mice (a gift from M. Bruce, BBSRC \& MRC Neuropathogenesis Unit, Edinburgh) were inoculated with strains $87 \mathrm{~V}$ and 22A. The Chandler strain was passaged in outbred white Swiss (CD1) mice and transgenic Tg20 mice [(29a) obtained from C. Weissmann] that overexpressed $\operatorname{PrP}^{\mathrm{C}}$. The scrapie strain 263K (obtained from $\mathrm{H}$. Diringer, Robert Koch Institute, Berlin) was used to infect Syrian hamsters. The Hessenl isolate was derived from a field case of scrapie in a 4-year-old Suffolk ram (30) and was isolated and subpassaged in C57BL/6 mice. Isolates S833 and S540 from the brain of Suffolk sheep that had been naturally infected by scrapie were transmitted to C57BL/6 mice by primary passage. BSE strains isolated from cattle that had developed BSE in the United Kingdom (BSE-UK; courtesy of R. Bradley, Weybridge) and in Germany (BSE-G) were subpassaged in C57BL/6 and VM95 mice. To prevent mixing the strains by cross-contamination, all instruments for inoculation were porous-load autoclaved at $136^{\circ} \mathrm{C}$ and 3 bars for $4 \mathrm{hr}$ prior to use and the animals were kept in isolation in facilities set up for this purpose for the respective scrapie strain. At the clinical stage of the disease, the animals were killed and their brains removed and stored at $-20^{\circ} \mathrm{C}$. Conservation of strain-specific characteristics were monitored by brain-lesion profile-scoring performed on indicator mice (data not shown). The measurement of the incubation period was calculated as the interval between inoculation and the well-defined appearance of typical symptoms of scrapie disease.

\section{Preparation of Brain Homogenates and Purification of Prion Proteins (SAFs)}

For each strain or isolate, separate brain homogenates from individual mice were examined separately and the pools contained brain tissues of several animals. Brain tissues were homogenized in phosphate-buffered saline (PBS) containing $0.5 \% \mathrm{NP}-40$ and $0.5 \%$ sodium deoxycholate (27) and were sonicated for 20-30 sec. Debris was removed by centrifugation at $2000 \mathrm{rpm}$ for 5 min and supernatants $[10 \%(\mathrm{w} / \mathrm{v})$ homogenates] were stored at $-20^{\circ} \mathrm{C}$.

$\mathrm{PrP}^{\mathrm{Sc}}$ was purified using a modified protocol as described previously (8). In summary, brain tissue was homogenized in brain lysis buffer (10 $\mathrm{mM}$ sodium phosphate containing $10 \% \mathrm{~N}$-lauryl-sarcosinate, $3 \mathrm{mM}$ phenylmethylsulfonylfluoride (PMSF), and $3 \mathrm{mM} N$-ethylmaleimide). Cell detritus was pelleted at 20,000 rpm for $5 \mathrm{~min}$ and in a further centrifugation step fibrils were pelleted at $100,000 \mathrm{rpm}$ for $30 \mathrm{~min}$.
Fig. 1. Long-term proteinase $K$ sensitivity of PrP $^{\text {Sc }}$ derived from different scrapie and BSE strains (A) or field isolates (B). To investigate the sensitivity of scrapie and BSE strains, isolates to proteinase $\mathrm{K}$ prion rods were purified from mouse brain homogenate pools (a minimum of four mice per trial) by differential centrifugation. Fractions containing $\operatorname{PrP}^{\mathrm{Sc}}$ were standardized according to their protein concentrations and signal intensities. Aliquots were subsequently exposed to $50 \mu \mathrm{g} / \mathrm{ml}$ (final concentration) proteinase $\mathrm{K}$ for 1 , $3,6,24$, or $48 \mathrm{hr}$ at $37^{\circ} \mathrm{C}$. Residual $\mathrm{PrP}^{\mathrm{Sc}}$ was then visualized by immunoblot and total band signals quantified by the photoimager technique. Residual $\mathrm{PrP}^{\mathrm{Sc}}$ antigen signals were calculated as arithmetic means from a minimum of two extraction and digestion experiments per strain. Each sample taken was analyzed on at least four different immunoblots. Combined PrP ${ }^{\mathrm{Sc}}$ signals (non-, mono- and diglycosylated bands) obtained after $1 \mathrm{hr}$ of proteolysis were set at $100 \%$ to minimize artefacts because of the possible initial contamination of fibrils with other proteins. Standard error values are indicated. 


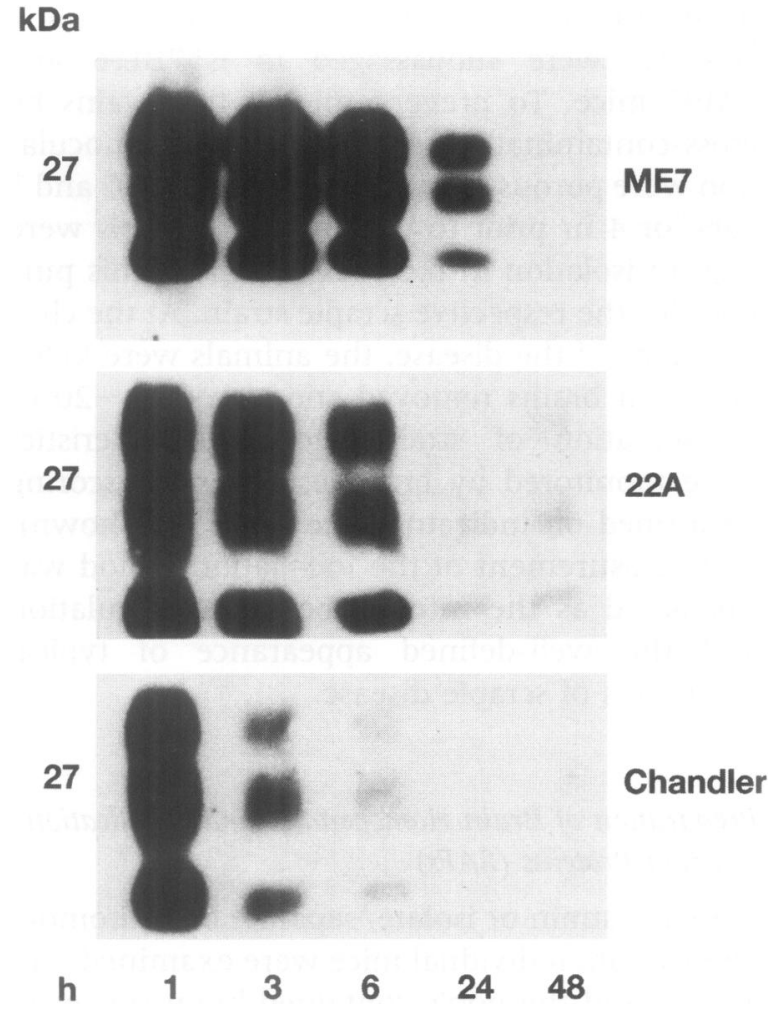

Fig. 2. Immunoblot depicting the difference in long-term stability of PrP ${ }^{S c}$ fibrils during proteinase $\mathbf{K}$ digestion. Scrapie strains ME7, 22A, and Chandler were propagated in C57BL/6 mice. Fibrils were incubated with $50 \mu \mathrm{g} / \mathrm{ml}$ (final concentration) proteinase $\mathrm{K}$ for $1,3,6,24$, and $48 \mathrm{hr}$. Proteinase $\mathrm{K}$ activity of samples taken at each time point was halted by the addition of PMSF (final concentration, $5 \mathrm{mM}$ ) followed by heating at $95^{\circ} \mathrm{C}$ for $15 \mathrm{~min}$. Samples were run on $16 \%$ SDS-PAGE gels and immunoblotted using the polyclonal anti-peptide antibody Ra5/7 to mouse PrP (residues 95-110).

Pellets were resolubilized in $16 \mathrm{mM}$ Tris buffer $(\mathrm{pH} 7.4)$ and incubated at $37^{\circ} \mathrm{C}$. After $30 \mathrm{~min}$, potassium iodide buffer ( $15 \%$ potassium iodide, $60 \mathrm{mM}$ sodium thiosulfate 5 -hydrochloride, 10 $\mathrm{mM}$ Tris buffer, $\mathrm{pH}$ 7.4) was added and samples were incubated for another $30 \mathrm{~min}$ at $37^{\circ} \mathrm{C}$. After adding potassium iodide buffer $(10 \%)$ to each sample, fibrillar structures were pelleted at $100,000 \mathrm{rpm}$ for $30 \mathrm{~min}$, supernatants were removed, and pellets were dried.

\section{Treatment with Proteinase $K$ and PNGaseF}

To digest $\mathrm{PrP}^{\mathrm{Sc}}$ of homogenates or SAFs, proteinase $\mathrm{K}(50 \mu \mathrm{g} / \mathrm{ml})$ was added to the sample and incubation was carried out for $1 \mathrm{hr}\left(37^{\circ} \mathrm{C}\right)$, unless otherwise indicated. Digestion was terminated by adding $5 \mathrm{mM}$ PMSF (Boehringer Mannheim,
Mannheim, Germany) and heating the samples at $95^{\circ} \mathrm{C}$ for $15 \mathrm{~min}$. For deglycosylation, the proteinase $\mathrm{K}$-treated samples were digested with 10 $\mathrm{mU} / \mathrm{ml}$ PNGaseF (Boehringer, Mannheim) for 6 $\mathrm{hr}$ at $37^{\circ} \mathrm{C}$. The reaction was terminated by heating to $95^{\circ} \mathrm{C}$ for $15 \mathrm{~min}$ and the samples were stored at $-20^{\circ} \mathrm{C}$.

\section{Immunoblot Analysis}

Electrophoretic separation of proteins by sodium dodecyl sulfate-polyacrylamide gel electrophoresis (SDS-PAGE) on a mini-slab-gel apparatus (Mini-protein II dual slab cell, Biorad, Munich) was performed with $16 \%$ or $20 \%$ polyacrylamide gels as previously described (31). Before loading onto the gels, the samples were suspended in SDS-loading buffer and heated to $95^{\circ} \mathrm{C}$ for $5 \mathrm{~min}$. Proteins were electroblotted onto Immobilon-P membranes (Millipore, Bedford, MA) using a semi-dry blotting system (Biorad). Membranes were blocked in PBS containing $0.05 \%$ TWEEN 20 (PBST), 5\% non-fat milk powder, and $5 \%$ fetal calf serum (FCS) and were incubated with a mouse-specific polyclonal antipeptide rabbit antibody Ra5/7 at 1:2000 dilution in blocking buffer to detect mouse-passaged $\mathrm{PrP}^{\mathrm{Sc}}$. This antibody was raised to the amino terminus of mouse $\operatorname{PrP}^{\mathrm{Sc}}$ (amino acids 95-110: THNQWNKPSKPKTNMK). To detect hamsterpassaged $\mathrm{PrP}^{\mathrm{Sc}}$, the monoclonal antibody $3 \mathrm{~F} 4$ was used at a dilution of 1:5000 in PBST. Horseradish peroxidase-conjugated affinity-purified goat anti-rabbit immunoglobulin G (IgG) or goat anti-mouse IgG (Dianova, Hamburg, Germany) served as the detection antibody. The membranes were developed using a chemiluminescence enhancement kit (ECL, Amersham, Little Chalfont, UK) and the protein bands were visualized on high-performance luminescence detection films (Hyperfilm ECL, Amersham).

\section{Quantitative and Statistical Analysis}

In order to glycotype the PrP strains or isolates, the banding intensities of the non-, mono-, and diglycosylated $\operatorname{PrP}$ isoforms were determined in the linear range of light emission, which was verified for each strain or isolate by analyzing serially diluted samples after digestion of $\mathrm{PrP}^{\mathrm{Sc}}$ with proteinase $\mathrm{K}$ for $1 \mathrm{hr}$ at $37^{\circ} \mathrm{C}$, as previously described (29). The signal bands were scanned on a chemiluminescence photoimager (Fujifilm, Düsseldorf, Germany) with the CSC program. For quantification, the banding intensities of the non-, 


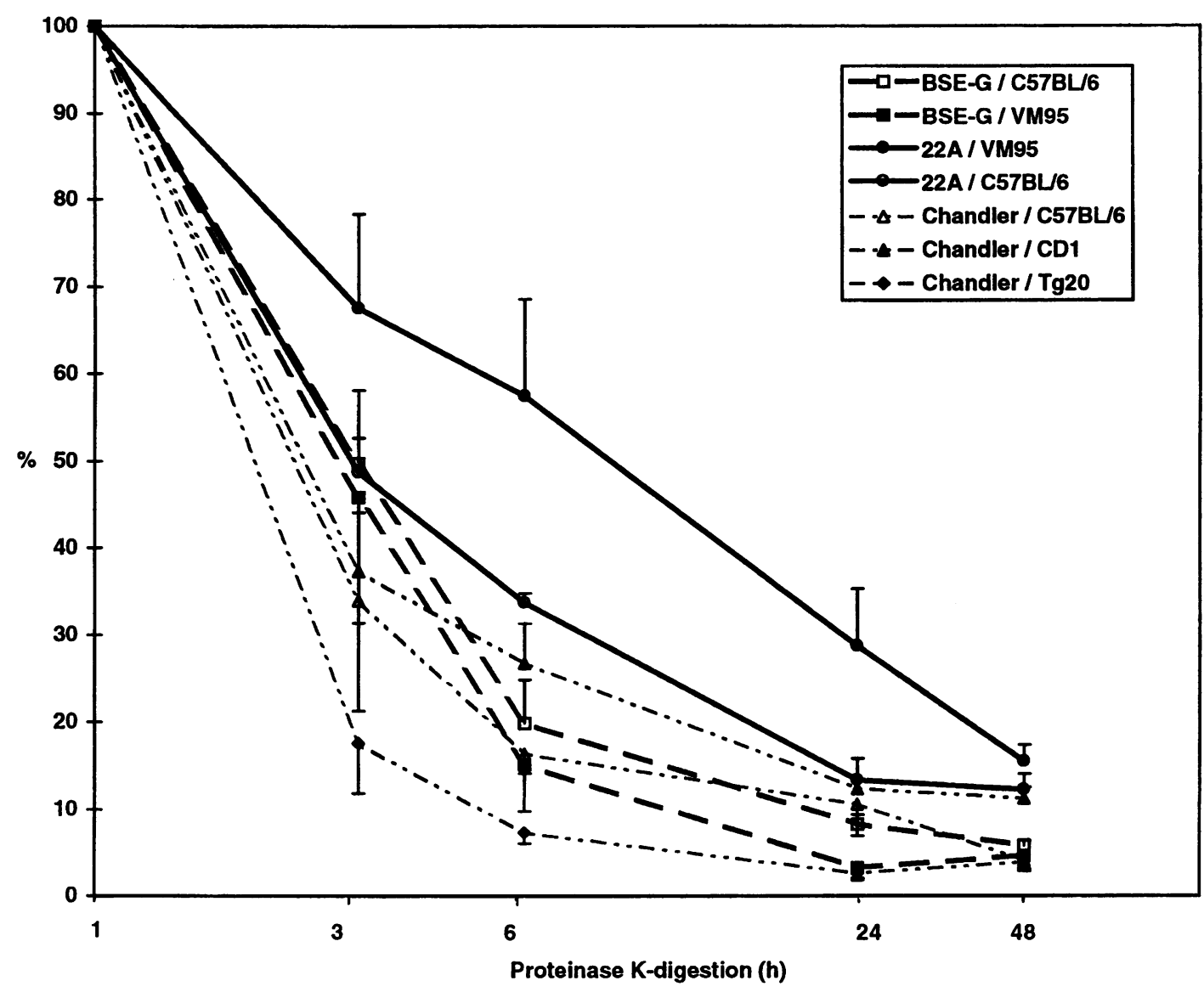

Fig. 3. Analysis of long-term stability of proteinase $K$ of strains $22 A$, Chandler, and BSE-G propagated in different mouse lines. $\operatorname{PrP}^{\mathrm{SC}}$ was purified from pooled mouse brain homogenates (mouse lines Tg20, C57BL/6, CD-1, and VM95) and exposed to proteinase $\mathrm{K}$ for $1,3,6,24$, or $48 \mathrm{hr}$ at

mono- and diglycosylated PrP isoforms were determined with the TINA2.0 program and calculated as described (32). For experiments determining longterm proteinase $\mathrm{K}$ resistance, signal intensities of digested pooled $\operatorname{PrP}^{S c}(1 \mathrm{hr})$ were defined as $100 \%$ for each strain, respectively, and the percentages of long-term hydrolyses were calculated. Standard errors were calculated from the means of different gel runs. For the calculation of $\operatorname{PrP}^{\mathrm{Sc}}$ deposits in different brain regions, identical amounts of each homogenate and of each individual animal were loaded onto the gels. Protein intensities of the investigated areas in an individual animal were determined and the deposits were calculated as percentages of the total signals. After separate SDSPAGE and immunoblotting, the deposits were analyzed by calculating the means of each individual. The standard errors were assessed from the means of the animals for each PrP banding pattern $37^{\circ} \mathrm{C}$ prior to immunoblot analysis. Combined $\operatorname{PrP}^{\mathrm{Sc}}$ signals were recorded using the photoimager technique and arithmetic means of at least four runs per sample were calculated. Standard error values are indicated.

to analyze the differences among individuals. To exclude variations in the separations in different SDS-PAGE runs, each brain homogenate was electrophoresed, immunoblotted, and scanned at least four times. Relative $\operatorname{PrP}^{S c}$ amounts of different scrapie and BSE strains or isolates were determined by photoimager recording of immunoblot signals' combined values of all three glycoforms. Standard error values were calculated from means of the gels runs of the individual animals tested.

\section{Results}

In the current study, six phenotypically welldefined rodent scrapie strains $(87 \mathrm{~V}, 79 \mathrm{~A}$, Chandler, 22A, ME7, 263K) as well as five mousepassaged field BSE (BSE-G and BSE-UK) and scrapie (Hessen1, S833, and S540) isolates were 


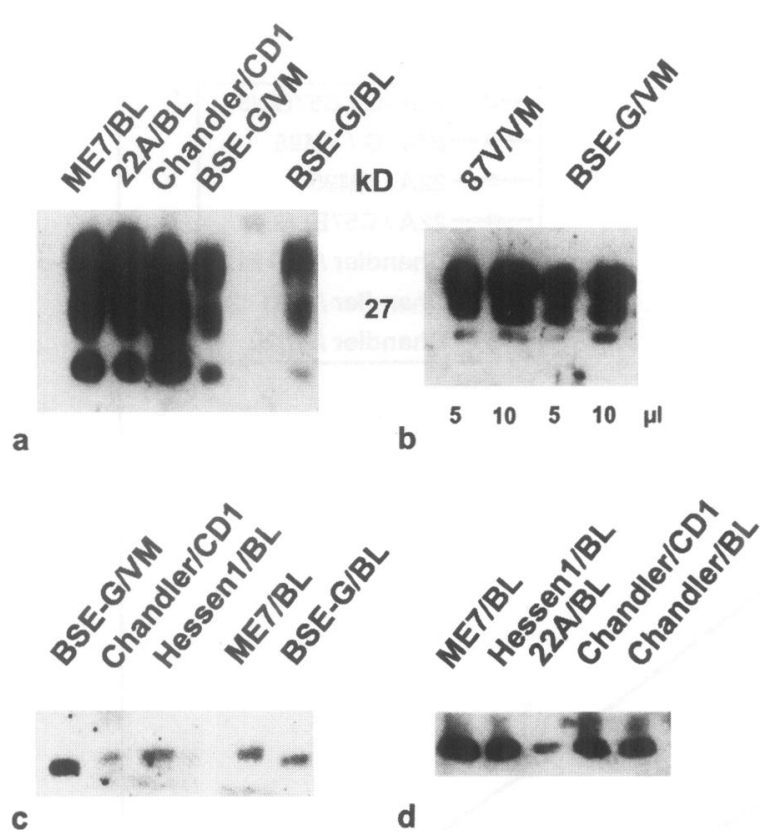

Fig. 4. Molecular mass of proteinase $\mathrm{K}$-treated PrP $^{S c}$ elicited by different scrapie and BSE strains or isolates. Brain homogenates (10\%) from C57BL/6 (BL), VM95 (VM), and CD-1 mice infected with different mouse-adapted BSE isolates and scrapie strains were treated with $50 \mu \mathrm{g} / \mathrm{ml}$ proteinase $\mathrm{K}$ for $1 \mathrm{hr}$ at $37^{\circ} \mathrm{C}$ and run on $20 \%$ (a) or $16 \%$ SDS-PAGE (b-d) gels. PrP ${ }^{\text {Sc }}$ bands were revealed by immunoblotting using a rabbit anti-peptide antibody to mouse PrP sequences (aa 95-110). In $\mathrm{c}$ and $\mathrm{d}$, $\mathrm{PrP}^{\mathrm{SC}}$ was deglycosylated by PNGase F treatment in addition to the proteinase $\mathrm{K}$ cleavage.

propagated in at least one out of four different conventional or transgenic mouse lines or in Syrian hamsters (Table 1). All strains and isolates led to the typical characteristics of scrapie disease after unique incubation times in the animals, which formed one basis for their discrimination. $\mathrm{PrP}^{\mathrm{Sc}}$ molecules accumulated in the neuronal systems were subsequently analyzed with respect to their glycosylation patterns after proteinase $\mathrm{K}$ digestion.

\section{Long-Term Resistance of $\mathrm{PrP}^{S c}$ to Proteinase $\mathrm{K}$}

Abnormal $\operatorname{PrP}\left(\mathrm{PrP}^{\mathrm{Sc}}\right)$ was purified from brain tissue samples of the infected mice and hamsters by standard procedures established for the preparation of scrapie-associated fibrils. Fibrils were subsequently exposed for prolonged times $(1,3$, $6,24$, and $48 \mathrm{hr})$ to proteinase $\mathrm{K}(50 \mu \mathrm{g} / \mathrm{ml})$ to determine their relative proteolytic stability. Non-degraded $\operatorname{PrP}^{\mathrm{Sc}}$ compounds were visualized as immunoblots using an antiserum to the amino terminus of the proteinase $\mathrm{K}$-resistant $\mathrm{PrP}^{\mathrm{Sc}}$ and residual antigen amounts quantified using enhanced chemiluminescence and photoimager techniques. In this set of experiments, banding signal intensities of $\mathrm{PrP}^{\mathrm{Sc}}$ after digestion with proteinase $\mathrm{K}$ for $\mathrm{l} \mathrm{hr}$ were defined as $100 \%$ for each strain or isolate. $\operatorname{PrP}^{\mathrm{C}}$ was proteolytically degraded entirely in this process. To minimize artefacts, all experiments were performed in duplicate and each sample was run on SDS-PAGE gels, immunoblotted, and analyzed in quadruplicate. To exclude specific effects arising from the mouse line involved, all BSE and scrapie strains (except 87V and 263K) used in this experiment were propagated in C57BL/6 mice. Most interestingly, PrP ${ }^{\mathrm{Sc}}$ did not show a uniform resistance to proteinase $\mathrm{K}$ treatment (Figs. 1A, B, 2). PrP $\mathrm{P}^{\mathrm{Sc}}$ antigenicity of scrapie strain Chandler in C57BL/ 6 mice was degraded by as much as $84 \%$ after only $6 \mathrm{hr}$ of exposure, whereas $\mathrm{PrP}^{\mathrm{Sc}}$ of strain $87 \mathrm{~V}$ was reduced by only $19 \%$ under identical conditions. Strain ME7 exhibited a similar proteinase $\mathrm{K}$ resistance to $87 \mathrm{~V}$ with a reduction of $\mathrm{PrP}^{\mathrm{Sc}}$ amounting to as little as $17 \%$ (Fig. 1A). The strains $22 \mathrm{~A}$ and $263 \mathrm{~K}$ had intermediate proteinase $\mathrm{K}$ resistance. $\mathrm{PrP}^{\mathrm{Sc}}$ of $22 \mathrm{~A}$ was decreased by $66 \%$ and $\operatorname{PrP}^{S c}$ of $263 \mathrm{~K}$ was reduced by $36 \%$. However, an initially low proteinase $\mathrm{K}$ degradation rate did not automatically indicate that $\mathrm{PrP}^{\mathrm{Sc}}$ resisted proteolytic cleavage to the same relative degree for extended times. After $48 \mathrm{hr}$ of proteinase $\mathrm{K}$ exposure, the degree of $\mathrm{PrP}^{\mathrm{Sc}}$ degradation of strains $87 \mathrm{~V}, \mathrm{ME7}$, Chandler, 22A, and $263 \mathrm{~K}$ was $86 \%, 94 \%, 99 \%, 88 \%$, and $57 \%$, respectively (Figs. 1A, 2). Thus, $\operatorname{PrP}^{\mathrm{Sc}}$ of strain $263 \mathrm{~K}$ was highly stable to extended proteinase $\mathrm{K}$ exposure (even beyond $72 \mathrm{hr}$ of exposure; data not shown).

$\mathrm{PrP}^{\mathrm{Sc}}$ from field isolates of scrapie, retrieved, and passaged in C57BL/6 mice was as disparate in long-term proteinase $\mathrm{K}$ stability as that from the defined BSE and scrapie strains (Fig. 1B). While over $90 \%$ of $\mathrm{PrP}^{\mathrm{Sc}}$ from isolate $\mathrm{S} 540$ was diminished after $6 \mathrm{hr}$ of incubation, the Hessen 1 $\mathrm{PrP}^{\mathrm{Sc}}$ isolate was almost entirely proteinase $\mathrm{K}$-resistant. Scrapie isolate $\mathbf{8} 833$ along with the BSE isolates showed intermediate susceptibility ( $34 \%$ reduction after $6 \mathrm{hr}$ of exposure). $\mathrm{PrP}^{\mathrm{SC}}$ of BSE-G and BSE-UK was degraded by $80 \%$ and $63 \%$, respectively, after $6 \mathrm{hr}$ of exposure.

In a second set of experiments, the influence of the different mouse lines used for propagation of TSE agents was analyzed. C57BL/6, CD1, and Tg20 carry the mouse prion allele Prnp ${ }^{a}$ in homozygous form, while VM95 mice harbor the Prnp ${ }^{b}$ allele. No effect of the mouse line used for 


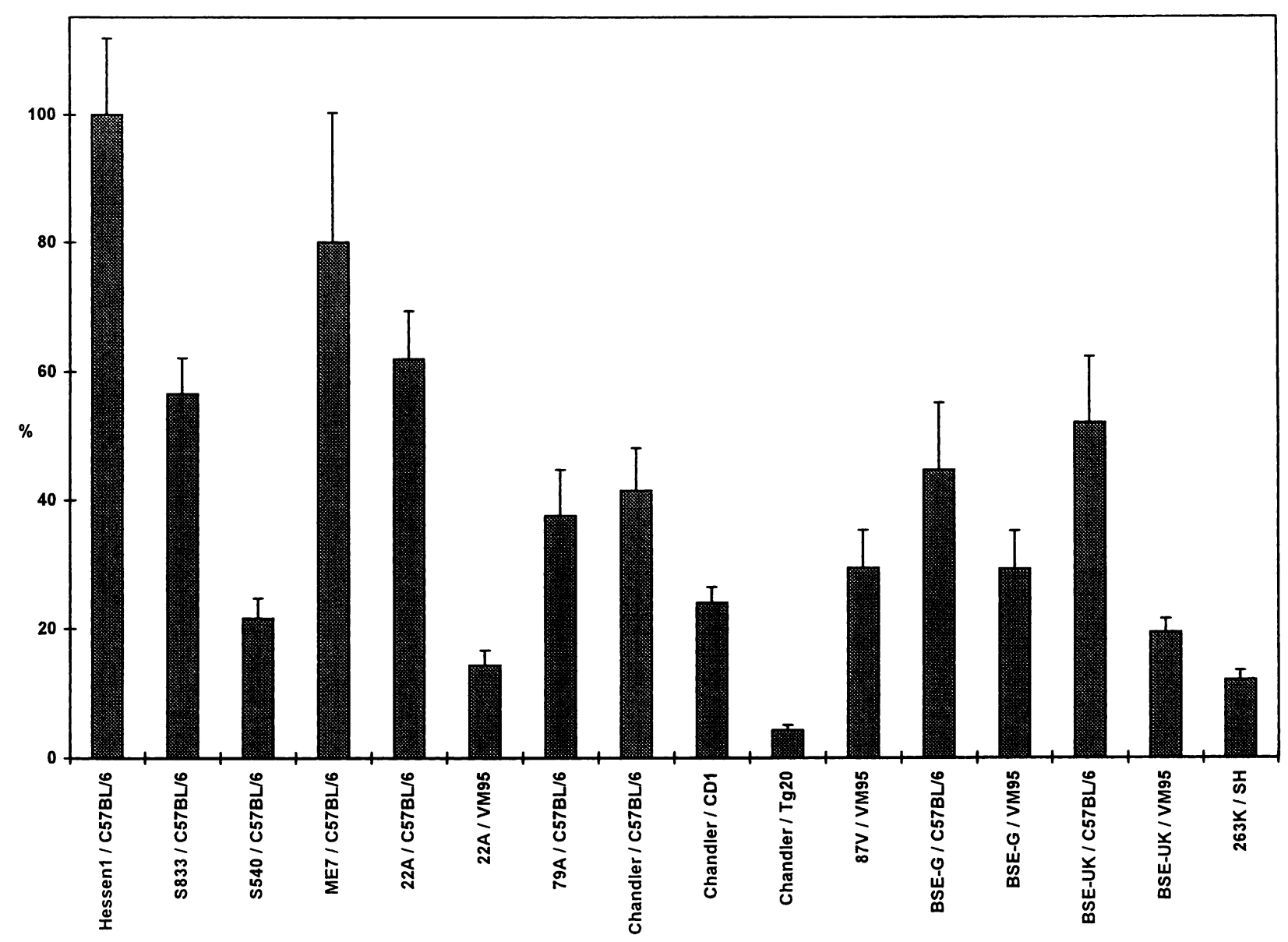

Fig. 5. Relative amounts of $\operatorname{PrP}^{S c}$ in different scrapie and BSE strains or isolates. Proteins of pooled brain homogenates $(10 \%)$ were separated by SDS-PAGE gel runs $(16 \%)$ after proteinase $\mathrm{K}$ digestion and immunoblotted using a rabbit anti-peptide serum to mouse PrP sequences. For quantification of the signals, protein bands were scanned on a chemiluminescence photoimager. Reciprocal values from homogenates of different mouse lines infected with the appropriate scrapie and BSE strains or isolates to give identical signal intensities are depicted. Overall percentages were calculated as arithmetical means \pm standard error of the means (SEM) of individual mice. The following numbers of mice and SDS-PAGE

propagation was observed for the BSE-G isolate or for the scrapie strain Chandler. However, a slight, yet statistically significant difference in long-term proteinase $\mathrm{K}$ resistance was found in $\mathrm{PrP}^{\mathrm{SC}}$ of scrapie strain 22A propagated in VM95 or C57BL/6 mice. This was all the more remarkable, as all $\operatorname{PrP}^{\mathrm{Sc}}$ displayed strain-specific glycotyping patterns independent of the mouse type in which they were tested (data not shown). Thus, depending on the prion strain, the mouse line used as $\mathrm{PrP}^{\mathrm{Sc}}$ source may have an effect, were included into each calculation: C57BL/6 mice were infected with Hessen l (homogenates of 5 mice divided up into 31 gels), S833 (4 mice/16 gels), S540 (4 mice/26 gels), ME7 (5 mice/27 gels), 22A (5 mice/17 gels), 79A (6 mice/23 gels), Chandler (6 mice/39 gels), BSE-G (5 mice/30 gels), and BSE-UK (5 mice/24 gels). VM95 mice were inoculated with 87V (6 mice/32 gels), 22A (4 mice/16 gels), BSE-G (4 mice/22 gels) and BSE-UK (4 mice/21 gels). The Chandler strain was used to infect both CD-1 (8 mice/43 gels) and Tg20 mice (4 mice/16 gels). Syrian hamsters $(\mathrm{SH})$ were inoculated with $263 \mathrm{~K}(4$ hamsters/16 gels). albeit minor, on its long-term proteinase $\mathrm{K}$ stability (Fig. 3).

\section{Molecular Mass of $\mathrm{PrP}^{S c}$ after Proteinase $\mathrm{K}$ Cleavage}

Proteinase $\mathrm{K}$-treated brain homogenates of mice infected with strains BSE, 87V, 22A, Hessenl, Chandler, and 79A were run on high-resolution SDS-PAGE gels and PrPSc bands were visualized by immunoblotting. As expected, the molecular mass of nonglycosylated $\operatorname{PrP}^{\mathrm{Sc}}$ in almost all 
strains averaged $21 \mathrm{kD}$ (Fig. 4). However, as previously described (25), $\operatorname{PrP}^{\mathrm{Sc}}$ of strain $87 \mathrm{~V}$ was cleaved by proteinase $\mathrm{K}$ to a $1-2 \mathrm{kD}$ smaller fragment (molecular mass approximately 19 $\mathrm{kD})$. As already demonstrated by the comparison of $\mathrm{PrP}^{\mathrm{Sc}}$ produced in different species, the same characteristic could now be observed for both mouse-passaged BSE isolates: nonglycosylated proteinase $\mathrm{K}$-degraded $\operatorname{PrP}^{\mathrm{Sc}}$ molecules from mouse-passaged BSE isolates exhibited a lower molecular mass than those from the other scrapie strains. This difference was independent of mouse line (C57BL/6 or VM95 mice) used for propagation of $\mathrm{BSE} \mathrm{PrP}^{\mathrm{Sc}}$.

\section{Relative Amounts of $\mathrm{PrP}^{S c}$ Deposits}

Relative amounts of $\mathrm{PrP}^{\mathrm{Sc}}$ deposits induced by the infection of mice with different prion strains or isolates were determined by photoimager recording of immunoblot signals (combined values of all three glycoforms). The most abundant $\mathrm{PrP}^{\mathrm{Sc}}$ accumulation was found in C57BL/6 mice infected with the scrapie isolate Hessen 1, which was thus set at $100 \%$ (Fig. 5). Similarly, pronounced accumulation levels were also observed in C57BL/6 mice infected with the mouseadapted strain ME7 (Fig. 5). Intermediate $\mathrm{PrP}^{\mathrm{Sc}}$ accumulation levels were found in $\mathrm{C} 57 \mathrm{BL} / 6$ mice infected by 22A, 79A, Chandler, BSE-G, and BSE-UK. Interestingly, the levels of $\mathrm{PrP}^{\mathrm{SC}}$ produced were dependent of the respective mouse line used. $\mathrm{PrP}^{S \mathrm{Sc}}$ accumulation levels of all strains were lower in VM95 mice. Moreover, the neuronal overexpression of mouse $\operatorname{PrP}^{C}$ in transgenic $\mathrm{Tg} 20$ mice (a factor of 10) did not give rise to elevated $\operatorname{PrP}^{\mathrm{Sc}}$ amounts after inoculation with Chandler strain. Rather, $\mathrm{PrP}^{\mathrm{Sc}}$ levels were eight times higher in C57BL/6 and five times higher in CD1 than in $\operatorname{Tg} 20$ mice.

\section{Distribution of $\mathrm{PrP}^{S c}$ Deposits}

Consistent differences among the TSE strains were also observed with regard to the localization of $\mathrm{PrP}^{\mathrm{Sc}}$ deposits in the brains of scrapie- and BSE-diseased mice (Fig. 6). In VM95 mice infected with either scrapie strain $87 \mathrm{~V}$ or with BSE, $\mathrm{PrP}^{\mathrm{Sc}}$ was accumulated largely in the brain stem. Interestingly, both BSE isolates exhibited the same deposition pattern in VM95 mice. In contrast, infection with strain $22 \mathrm{~A}$ led to major $\mathrm{PrP}^{\mathrm{Sc}}$ deposits in the cerebellum. Scrapie isolates Hessenl and S833 differed in $\operatorname{PrP}^{\mathrm{Sc}}$ distribution in the brain. Whereas $\operatorname{PrP}^{\mathrm{Sc}}$ of Hessenl accumu-

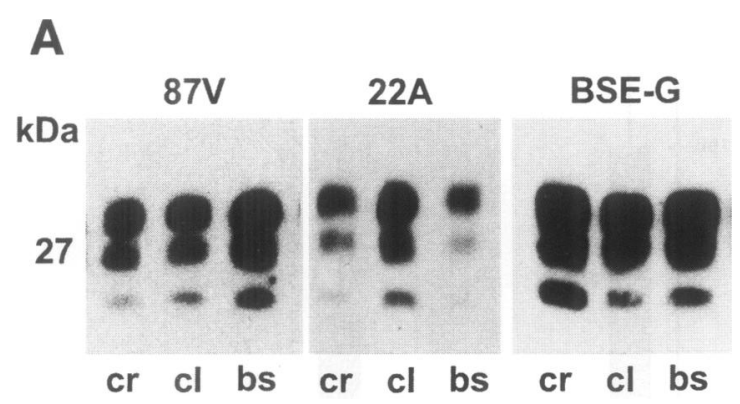

Fig. 6. Distribution of $\operatorname{PrP}^{S c}$ deposits in different brain areas. Relative amounts of $\operatorname{PrP}^{\mathrm{sc}}$ deposits in the cerebrum (cr), cerebellum (cl), and brain stem (bs) were determined by immunoblotting (A) and quantification through the photoimager technique (B). Relative percentages of cerebrum, cerebellum, and brain stem were calculated as arithmetic means \pm standard error of the means of individual mouse homogenates. VM95 mice were inoculated with 87V (6 mice/24 gels); BSE-UK (4 mice/16 gels); BSE-G (4 mice/24 gels); and 22A (4 mice/19 gels). C57BL/6 mice were inoculated with 22A (4 mice/18 gels); Chandler ( 5 mice/31 gels); 79A ( 3 mice/12 gels); BSE-G (3 mice/26 gels); Hessenl (4 mice/19 gels); and S833 (4 mice/16 gels). Outbred CD-1 mice were inoculated with Chandler (6 mice/34 gels). Tg20 mice were inoculated with the Chandler strain (4 mice/16 gels) and Syrian hamsters (SH) were inoculated with 263K (4 hamsters/16 gels).

lated largely in the brain stem, major $\operatorname{PrP}^{\mathrm{Sc}}$ deposits of S833 were detected in the cerebellum, as with strain $22 \mathrm{~A}$.

\section{Discussion}

There is a growing need to establish criteria for distinguishing TSE agents. Variations among scrapie, BSE, and CJD strains and isolates were detected by the glycotyping technique (27-29), but this technique does not discriminate every individual strain. In the present work, we have selected a number of biochemical and biological markers of $\mathrm{PrP}^{\mathrm{Sc}}$, which have not yet been studied in detail for their application in BSE and scrapie strains and isolates; as it turned out, these markers are useful in distinguishing prion strains more precisely.

We have analyzed the long-term proteinase $\mathrm{K}$ resistance, molecular mass of $\mathrm{PrP}^{\mathrm{Sc}}$, and topology and quantity of the $\operatorname{PrP}^{\mathrm{Sc}}$ deposits. Our results demonstrate that $\operatorname{PrP}^{\mathrm{Sc}}$ proteins of different BSE and scrapie strains consistently display differences in their long-term proteinase $\mathrm{K}$ resistance. For example, $\mathrm{PrP}^{\mathrm{Sc}}$ of $87 \mathrm{~V}$ and ME7 were relatively stable to proteinase $\mathrm{K}$ hydrolysis for up 


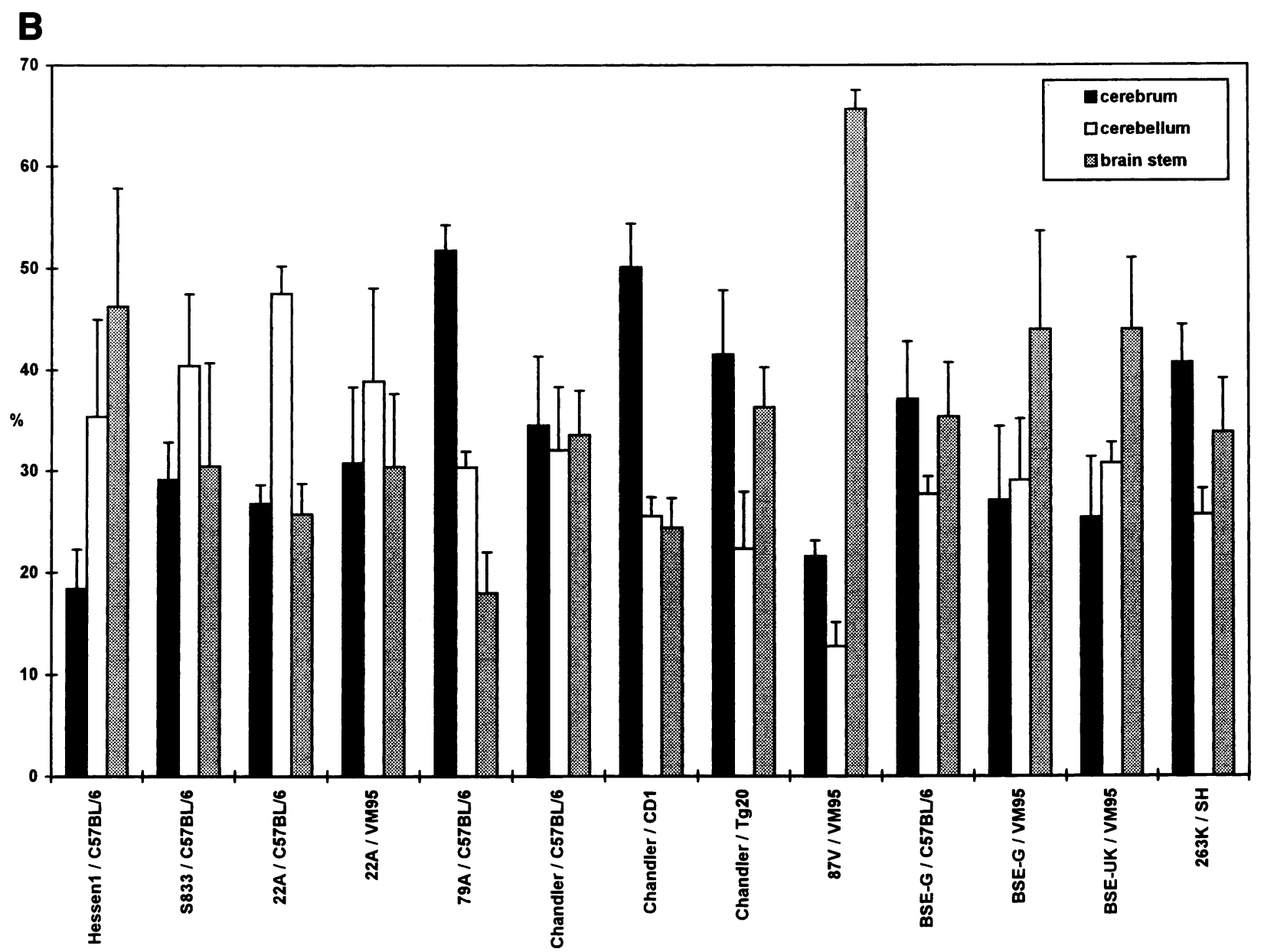

Fig. 6. Continued

to $24 \mathrm{hr}$ of digestion, whereas $\mathrm{PrP}^{\mathrm{Sc}}$ of the Chandler strain was almost completely destroyed after as little as $6 \mathrm{hr}$ of exposure. $\operatorname{PrP}^{\mathrm{Sc}}$ of scrapie strains $22 \mathrm{~A}$ and $263 \mathrm{~K}$ displayed intermediate resistance. Interestingly, field scrapie isolates in mice were not as diverse as experimental scrapie strains. While the Hessenl isolate $\operatorname{PrP}^{\mathrm{Sc}}$ was almost totally proteinase $\mathrm{K}$-resistant, $\operatorname{PrP}^{\mathrm{Sc}}$ of isolates S833 and S540 exhibited intermediate and high sensitivity to this enzyme. In comparison to most other scrapie strains, $\mathrm{PrP}^{\mathrm{Sc}}$ of the BSE isolates exhibited intermediate resistance to proteinase $\mathrm{K}$ digestion. Scrapie strain $87 \mathrm{~V}$ and strains of BSE exhibited a very similar pattern of signal intensities of the non-, mono- and diglycosylated $\mathrm{PrP}^{\mathrm{SC}}$ isoform (29) but after long-term proteinase $\mathrm{K}$ treatment, both strains could be clearly distinguished, BSE $\operatorname{PrP}^{\mathrm{Sc}}$ being markedly less stable.

Our results are not unprecedented; strainspecific differences in the proteinase $\mathrm{K}$ stability of
$\mathrm{PrP}^{\mathrm{Sc}}$ compounds have already been observed. Kascsak et al. (25) exposed fibril preparations from scrapie strains 263K, 139A, and ME7 to proteinase $\mathrm{K}$ and separated the proteins on SDSPAGE gels. In these experiments, the three typical bands were weaker in varying degrees, indicating that $\mathrm{PrP}^{\mathrm{Sc}}$ of strain 139A was less resistant to proteinase $\mathrm{K}$ digestion than $\operatorname{PrP}^{\mathrm{Sc}}$ of scrapie 263K and ME7. Later, similar differences were observed for transmissible mink encephalopathy strains Hyper and Drowsy, the latter being less resistant to proteinase $\mathrm{K}$ treatment (26).

The species and particular breed used for the generation of $\mathrm{PrP}^{\mathrm{Sc}}$ may have an influence on its molecular characteristics. We compared $\mathrm{PrP}^{\mathrm{Sc}}$ generated in a variety of different mouse lines carrying prion alleles Prnp ${ }^{a}$ or Prnp ${ }^{b}$. These encode mouse PrP differing by polymorphisms at amino acids 108 (Leu/Phe) and 189 (Thr/Val) (33). According to our results, the effect of these polymorphisms on the long-term proteinase $\mathrm{K}$ 
resistance of $\operatorname{PrP}^{\mathrm{Sc}}$ is not entirely clear. While no differences were found in long-term proteinase $\mathrm{K}$ resistance of $\operatorname{PrP}^{\mathrm{Sc}}$ from the $\mathrm{BSE}-\mathrm{G}$ isolate propagated in homozygous Prnp ${ }^{\mathrm{a}}$ C57BL/6 mice and Prnp ${ }^{\mathrm{b}}$ VM95 mice, $\operatorname{PrP}^{\mathrm{Sc}_{\mathrm{S}}}$ of scrapie strain 22A propagated in these two different mouse lines were distinct from another. It has been reported that SAF proteins from scrapie strains ME7 and 87V isolated from different mouse lines differed in sensitivity to proteinase $\mathrm{K}$ (34), a result which contradicts that of another study that found no differences between strains 139A and ME7 (35).

The close linkage between $\operatorname{PrP}^{\mathrm{Sc}}$ and the infectious agent itself is indisputable. It would seem that the strain-specific characteristics of prion diseases are brought about, if not encoded, by differences in the $\operatorname{PrP}^{\mathrm{Sc}}$ conformations. Evidence for different conformations of several $\mathrm{PrP}^{\mathrm{Sc}}$ strains has been demonstrated recently through use of a highly sensitive conformationdependent immunoassay. Several hamster-passaged PrP strains differed in their conformation and each strain exhibited a distinct pattern (36). The underlying mechanisms for these strain-specific $\mathrm{PrP}^{\mathrm{Sc}}$ conformations are still unclear-either these differences are solely due to variations in structure and conformation of $\mathrm{PrP}^{\mathrm{Sc}}$ or to posttranslational modifications of PrP.

Another unique characteristic of $\mathrm{PrP}^{\mathrm{Sc}}$ from BSE isolates independent of the mouse line used is that proteinase $\mathrm{K}$-treated $\mathrm{PrP}^{\mathrm{Sc}}$ possesses a 1-2 $\mathrm{kD}$ lower molecular mass compared to similarly treated $\mathrm{PrP}^{\mathrm{Sc}}$ of other experimental scrapie strains. The same characteristic was revealed for scrapie strain $87 \mathrm{~V} \mathrm{PrP}{ }^{\mathrm{Sc}}$. However, none of the three German field isolates of scrapie included in this study induced the accumulation of proteinase $\mathrm{K}$-treated $\mathrm{PrP}^{\mathrm{Sc}}$ with such low molecular mass. Similar differences in the molecular mass of prion proteins were found for scrapie, as well as for BSE and human diseases such as CJD and FFI $(27,34,37)$. A conformational change of strain-specific $\mathrm{PrP}^{\mathrm{Sc}}$ could be one reason for differences in molecular mass, by additional N-terminal amino acids to proteinase $\mathrm{K}$ digestion. In addition to mouse lesion profile-scoring (38) and $\mathrm{PrP}^{\mathrm{Sc}}$ glycotyping, this characteristic of BSE-derived $\mathrm{PrP}^{\mathrm{Sc}}$ might therefore provide us with the first distinctive parameter for future discrimination of BSE and scrapie infections in small ruminants.

Total PrP ${ }^{\mathrm{Sc}}$ amounts were determined in proteinase $\mathrm{K}$-digested homogenates of mouse brain tissues. High levels were found in C57BL/6 mouse brains infected with the scrapie isolate Hessenl and strain ME7, respectively, and the lowest levels were detected in transgenic $\mathrm{Tg} 20$ mice infected with Chandler. The formed $\mathrm{PrP}^{\mathrm{Sc}}$ amounts differed in scrapie strains as well as in the mouse line used. In this way, we were able to recognize an influence according to the mouse line used. VM95 mice expressed less $\mathrm{PrP}^{\mathrm{Sc}}$ than C57BL/6 mice independent of the strain.

We compared the levels of PrP ${ }^{\text {Sc }}$ accumulation in the cerebrum, cerebellum, and brain stem of diseased mice. Substantial differences in the distribution of the $\operatorname{PrP}^{\mathrm{Sc}}$ deposits in these brain areas were found depending on the nature of the strain or isolate. By this criterion, scrapie strain $87 \mathrm{~V}$ could be distinguished from all other prion strains, including BSE isolates. While strain $87 \mathrm{~V}$ $\mathrm{PrP}^{\mathrm{SC}}$ is deposited most abundantly in the brain stem, BSE infection leads to a rather even range of $\mathrm{PrP}^{\mathrm{Sc}}$ deposits in the brain stem, cerebellum, and cerebrum. PrP ${ }^{\mathrm{Sc}}$ of strain $22 \mathrm{~A}$ is deposited primarily in the cerebellum of the mice. These results are in agreement with histoblot results on strain 22A mouse brains, with predominant $\mathrm{PrP}^{\mathrm{Sc}}$ staining in the cortex, granular cell layer of the cerebellum, hippocampus, and hypothalamus. Most $\operatorname{PrP}^{S C}$ of $87 \mathrm{~V}$ accumulated in the thalamus, locus ceruleus, and raphe nuclei of the brain stem; very few accumulated in the neocortex, hippocampus, and hypothalamus (39-40).

The inoculation of field agents of scrapie into C57BL/6 mice resulted in clearly different patterns. Each isolate had a specific incubation time, a particular amount of formed $\mathrm{PrP}^{\mathrm{Sc}}$, a characteristic distribution of $\mathrm{PrP}^{\mathrm{Sc}}$ deposits in brain areas, and a characteristic resistance to proteinase $\mathrm{K}$ digestion. Scrapie isolate $\mathbf{8 8 3 3}$ exhibited properties similar to those of strain $22 \mathrm{~A}$ with regard to proteinase $\mathrm{K}$ resistance and $\mathrm{PrP}^{\mathrm{Sc}}$ deposition in brain. This finding suggests that $22 \mathrm{~A}$ is a representative field strain of scrapie. Moreover, $\mathrm{PrP}^{\mathrm{Sc}}$ glycotyping profiles, molecular mass, and/or long-term PK resistance results obtained indicated that the three German field isolates of scrapie can be distinguished from the BSE isolates.

In summary, these studies have demonstrated that the $\operatorname{PrP}^{S c}$ elicited by distinct prion strains and isolates passaged in in- and outbred mouse lines has different but unique, strain-specific properties. Glycotyping of the non-, monoand diglycosylated $\operatorname{PrP}^{\mathrm{Sc}}$ isoforms, as well as analysis of the molecular mass of the protein bands, was not sufficient for providing a clear discrimination of some strains, such as scrapie 
strain $87 \mathrm{~V}$ and the BSE isolates. Through differences in long-term resistance to proteinase $K$ digestion, we were able to pinpoint a characteristic that helped us distinguish between these two strains/isolates. Analysis of the deposits and physicochemical characterization of $\operatorname{PrP}^{\mathrm{Sc}}$ in BSE and scrapie strains/isolates thus yield important information for the possible discrimination between strains. Furthermore, it seems that $\operatorname{PrP}^{\mathrm{Sc}}$ strains differ in their structural conformation; this can result in different proteinase $\mathrm{K}$ sensitivities, varying $\operatorname{PrP}^{S c}$ accumulations, deposition in different brain areas, and individual glycoform patterns.

\section{Acknowledgements}

We thank Roswitha Fischer for her excellent technical assistance. This work was supported in part by grants from the Bundesministerium für Ernährung, Landwirtschaft und Forsten, the Bundesministerium für Bildung, Wissenschaft und Technologie, and the EU Commission.

\section{References}

1. Bendheim PE, Barry RA, DeArmond SJ, Stites DP, Prusiner SB. (1984) Antibodies to a scrapie prion protein. Nature 310: 418-421.

2. DeArmond SJ, McKinley MP, Barry RA, Braunfeld MB, McColloch JR, Prusiner SB. (1985) Identification of prion amyloid filaments in scrapieinfected brain. Cell 41: 221-235.

3. Kitamoto T, Tateishi J, Tashima T, et al. (1986) Amyloid plaques in Creutzfeldt-Jakob disease stain with prion protein antibodies. Ann. Neurol. 20: 204-208.

4. Prusiner SB. (1991) Molecular biology of prion diseases. Science 252: 1515-1522.

5. Caughey B, Kocisko D, Priola SA, et al. (1996) Methods for studying prion protein (PrP) metabolism and the formation of protease-resistant PrP in cell culture and cell-free systems. In: Baker HF, Ridley RM (eds). Methods in Molecular Medicine: Prion Diseases. Humana Press, Totowa, NJ, pp. 285299.

6. Merz PA, Somerville RA, Wisniewski HM, Iqbal K. (1981) Abnormal fibrils from scrapie-infected brain. Acta Neuropathol. 54: 63-74.

7. Prusiner SB, Bolton DC, Groth DF, Bowman KA, Cochran SP, McKinley MP. (1982) Further purification and characterization of scrapie prions. Biochemistry 21: 6942-6950.

8. Diringer $H$, Gelderblom $H$, Hilmert $H$, Ozel $M$, Edelbluth C, Kimberlin RH. (1983) Scrapie infectivity, fibrils and low molecular weight protein. Nature 306: 476-478.
9. Prusiner SB, McKinley MP, Bowman KA, et al. (1983) Scrapie prions aggregate to form amyloidlike birefrigent rods. Cell 35: 349-358.

10. Barry RA, McKinley MP, Bendheim PE, Lewis GK, DeArmond SJ, Prusiner SB. (1985) Antibodies to the scrapie protein decorate prion rods. J. Immunol. 135: 603-613.

11. Bode L, Pocchiari $M$, Gelderblom H, Diringer $H$. (1985) Characterization of antisera against scrapieassociated fibrils (SAF) from affected hamster and cross-reactivity with SAF from scrapie-affected mice and from patients with Creutzfeldt-Jakob disease. J. Gen. Virol. 66: 2471-2478.

12. Bolton DC, McKinley MP, Prusiner SB. (1982) Identification of a protein that purifies with the scrapie prion. Science 218: 1309-1311.

13. Oesch B, Westaway D, Walchli $M$, et al. (1985) A cellular gene encodes scrapie $\operatorname{PrP}$ 27-30 protein. Cell 40: 735-746.

14. Caughey BW, Dong A, Bhat KS, Ernst D, Hayes SF, Caughey WS. (1991) Secondary structure analysis of the scrapie associated protein $\operatorname{PrP}$ 27-30 in water by infrared spectroscopy. Biochemistry 30: 7672-7680.

15. Pan KM, Baldwin M, Nguyen J, et al. (1993) Conversion of $\alpha$-helices into $\beta$-sheets features in the formation of the scrapie prion proteins. Proc. Natl. Acad. Sci. U.S.A. 90: 10962-10966.

16. Safar J, Roller PP, Gajdusek DC, Gibbs CJ Jr. (1993) Conformational transition, dissociation, and unfolding of scrapie amyloid (prion) protein. J. Biol. Chem. 268: 20276-20284.

17. Dickinson AG, Meikle VMH. (1971) Host-genotype and agent effects in scrapie incubation: change in allelic interaction with different strains of agent. Mol. Gen. Genet. 112: 73-79.

18. Dickinson AG. (1976) Scrapie in sheep and goats. In: Kimberlin RH (ed). Slow Virus Diseases of Animals and Man. North-Holland, Amsterdam, pp. 209-241.

19. Dickinson AG, Taylor DM. (1978) Resistance of scrapie to decontamination. N. Engl. J. Med. 299: 1413-1414.

20. Fraser H. (1979) Neuropathology of scrapie: the precision of the lesions and their diversity. In: Prusiner SB, Hadlow WJ (eds). Slow Transmissible Diseases of the Nervous System, Vol. 1. Academic Press, New York, pp. 387-406.

21. Kimberlin RH, Walker CA, Millson GC, et al. (1983) Disinfection studies with two strains of mouse-passaged scrapie agent. J. Neurol. Sci. 59: 355-369.

22. Bruce ME, Dickinson AG. (1987) Biological evidence that scrapie agent has an independent genome. J. Gen. Virol. 68: 78-89.

23. Kimberlin RH, Walker CA, Fraser H. (1989) The genomic identity of different strains of mouse scrapie is expressed in hamsters and preserved on reisolation in mice. J. Gen. Virol. 70: 20172025. 
24. Bruce ME, McConnell I, Fraser H, Dickinson AG. (1991) The disease characteristics of different strains of scrapie in SINC congenic mouse lines: implications for the nature of the agent and host control of pathogenesis. J. Gen. Virol. 72: 595-603.

25. Kascsak RJ, Rubenstein R, Merz PA, Carp RI, Wisniewski HM, Diringer H. (1985) Biochemical differences among scrapie-associated fibrils support the biological diversity of scrapie agents. J. Gen. Virol. 66: 1715-1717.

26. Bessen RA, Marsh RF. (1992) Biochemical and physical properties of the prion protein from two strains of the transmissible mink encephalopathy agent. J. Virol. 66: 2096-2101.

27. Collinge J, Sidle KCL, Meads J, Ironside J, Hill AF. (1996) Molecular analysis of prion strain variation and the aetiology of "new variant" CJD. Nature 383: 685-690.

28. Somerville RA, Chong A, Mulqueen OU, Birkett CR, Wood SCER, Hope J. (1997) Biochemical typing of scrapie strains. Nature 386: 564.

29. Kuczius T, Haist I, Groschup MH. (1998) Molecular analysis of bovine spongiform encephalopathy and scrapie strain variation. J. Infect. Dis. 178: 693-699.

29a.Fischer M, Rülicke T, Raeber A, et al. (1996) Prion protein (PrP) with amino-proximal deletions restoring susceptibility of PrP knockout mice to scrapie. EMBO J. 15: 1255-1264.

30. Groschup $\mathrm{MH}$, Weiland F, Straub OC, Pfaff E. (1996) Detection of scrapie agent in the peripheral nervous system of a diseased sheep. Neurobiol. Dis. 3: 191-195.

31. Groschup MH, Langeveld J, Pfaff E. (1994) The major species specific epitope of prion protein of ruminants. Arch. Virol. 136: 423-431.

32. Campbell RC. (1971) Statistische Methoden für Biologie und Medizin. Georg Thieme, Stuttgart.
33. Westaway D, Goodman PA, Mirenda CA, McKinley MP, Carlson GA, Prusiner SB. (1987) Distinct prion proteins in short and long scrapie incubation period mice. Cell 51: 651-662.

34. Kascsak RJ, Rubenstein R, Carb RI. (1991) Evidence for biological and structural diversity among scrapie strains. In: Chesebro BW (ed). Transmissible Spongiform Encephalopathies. Current Topics in Microbiology and Immunology. SpringerVerlag, Berlin, pp. 139-152.

35. Bockman JM, Kingsbury DT. (1988) Immunological analysis of host and agent effects on Creutzfeldt-Jakob disease and scrapie prion proteins. J. Virol. 62: 3120-3127.

36. Safar J, Wille H, Itri V, et al. (1998) Eight prion strains have $\operatorname{PrP}^{\mathrm{Sc}}$ molecules with different conformations. Nat. Med. 4: 1157-1165.

37. Telling GC, Parchi P, DeArmond SJ, et al. (1996) Evidence for the conformation of the pathologic isoform of the prion protein enciphering and propagating prion diversity. Science 274: 20792082.

38. Bruce ME, Chree A, McConnell I, Foster J, Pearson G, Fraser H. (1994) Transmission of bovine spongiform encephalopathy and scrapie to mice: strain variation and species barrier. Philos. Trans. R. Soc. Lond. B 343: 405-411.

39. Taraboulos A, Jendroska K, Serban D, Yang S-L, DeArmond SJ, Prusiner SB. (1992) Regional mapping of prion proteins in brains. Proc. Natl. Acad. Sci. U.S.A. 89: 7620-7624.

40. Carlson GA. (1996) Prion strains. In: Prusiner SB (ed). Prions Prions Prions. Springer-Verlag, Berlin, pp. 35-47. 